\title{
Changes in Diet and Body Condition of Lake Whitefish in Southern Lake Michigan Associated with Changes in Benthos
}

\author{
Steven A. Pothoven* \\ Cooperative Institute of Limnology and Ecosystem Research, \\ Great Lakes Environmental Research Laboratory, University of Michigan, \\ Lake Michigan Field Station, 1431 Beach Street, Muskegon, Michigan 49441, USA \\ Thomas F. NALEPA \\ National Oceanic and Atmospheric Administration, \\ Great Lakes Environmental Research Laboratory, \\ 2205 Commonwealth Boulevard, Ann Arbor, Michigan 48105, USA \\ Philip J. SchneEberger \\ Michigan Department of Natural Resources, Marquette Fisheries Research Station, \\ 484 Cherry Creek Road, Marquette, Michigan 49855, USA

\section{STEPHEN B. BRANDT} \\ National Oceanic and Atmospheric Administration, \\ Great Lakes Environmental Research Laboratory, \\ 2205 Commonwealth Boulevard, Ann Arbor, Michigan 48105, USA
}

\begin{abstract}
We evaluated the long-term trends of the benthic macroinvertebrate community (1980-1999) and biological attributes of lake whitefish Coregonus clupeaformis (1985-1999) in southeastern Lake Michigan. We also determined what food types were important to lake whitefish in an area where the amphipod Diporeia had not yet declined in 1998 and how the diet of lake whitefish changed as Diporeia declined during 1999-2000. Zebra mussels Dreissena polymorpha invaded the study area in 1992; Diporeia began to decline in 1993 and was nearly absent by 1999 . The body condition of lake whitefish decreased after 1993 and remained low thereafter. The length at age and weight at age of lake whitefish was lower in 1992-1999 than in 1985-1991. After declines of Diporeia off the city of Muskegon, Michigan, between 1998 and 1999-2000, the proportion of Diporeia in the diet by weight fell from $70 \%$ to $25 \%$ and the percent occurrence decreased from $81 \%$ to $45 \%$. In contrast, the proportion of lake whitefish that ate other prey, such as Mysis relicta (an opossum shrimp), ostracods, oligochaetes, and zooplankton, increased in the same period. At sites south of Muskegon, where the density of Diporeia has been low since 1998, chironomids, zebra mussels, and fingernail clams (Shaeriidae family) were the most important diet items of lake whitefish. Decreases in body condition and growth are associated with the loss of the high-energy prey resource Diporeia, the consumption of prey with lower energy content, such as zebra mussels, and possible density-dependence. Commercial harvests of lake whitefish will probably decrease because of low body condition and growth. Future management may require changes in harvest quotas, size restrictions, and depth restrictions as zebra mussel-related impacts spread northward in Lake Michigan.
\end{abstract}

Historically, lake whitefish Coregonus clupeaformis were a mainstay of the commercial fishery in Lake Michigan and other Laurentian Great Lakes (Fleischer 1992). A fishery collapse in Lake Michigan in the 1950s was attributed to pollution, overfishing, and pressure from sea lampreys $P e$ tromyzon marinus (Wells and McLain 1973). Lake whitefish stocks began to recover in Lake Michigan in the 1970s, and catches currently equal or

\footnotetext{
* Corresponding author: pothoven@glerl.noaa.gov
}

Received October 24, 2000; accepted April 16, 2001 exceed past levels (Baldwin et al. 2000). During 1990-1998, the average annual commercial harvest of lake whitefish from Lake Michigan was 3,305 metric tons, which accounted for nearly $40 \%$ of the total commercial catch in Lake Michigan (P. Schneeberger, Michigan Department of Natural Resources, unpublished data; Baldwin et al. 2000).

Zebra mussels Dreissena polymorpha invaded Lake Michigan in 1989 (Marsden et al. 1993) and quickly spread throughout nearshore areas of the southern basin (Nalepa et al. 1998). The benthic amphipod Diporeia began to decline in 1993 in southern Lake Michigan, perhaps because zebra 
mussels filtering limited food availability (Nalepa et al. 1998; 2000). Diporeia also declined after invasions by zebra mussels and quagga mussels Dreissena bugensis in Lake Ontario (Hoyle et al. 1999) and Lake Erie (Dermott and Kerec 1997). Diporeia are a trophic link between pelagic primary production and fish production in Lake Michigan (Gardner et al. 1985). Many fish species, including lake whitefish, that historically ate $D i$ poreia could be adversely affected if this prey becomes scarce (Ihssen et al. 1981; Jude et al. 1981; Hoyle et al. 1999).

Our first objective was to quantify long-term trends in the benthic macroinvertebrate community (1980-1999) and biological attributes of lake whitefish (1985-1999) in southeastern Lake Michigan. We expected that body condition, length at age, and weight at age of lake whitefish would decrease in association with changes in the benthos related to Dreissena invasion (Hoyle et al. 1999). Our second objective was to quantify the diet of lake whitefish relative to the abundance of Diporeia in southeastern Lake Michigan in 1998-2000. We expected that Diporeia would be an important component of the diet of lake whitefish and that, as Diporeia decreased, alternative prey (e.g., mollusks) would be eaten (Hoyle et al. 1999).

\section{Methods}

Benthic macroinvertebrates were collected from a site (H-31) located at a depth of $45 \mathrm{~m}$ off the city of Grand Haven, Michigan (Nalepa et al. 1998; Figure 1). Sampling occurred three times each year (spring, summer, autumn) in 1980-1981, 1986-1987, and 1992-1993 and one to six times each year in 1994-1999. Samples were taken in triplicate with a Ponar grab and washed through a $0.5-\mathrm{mm}$ nitex mesh net. Retained material was preserved in 5\% formalin containing rose bengal stain. Macroinvertebrates were identified and counted using a low-power magnifier lamp $(1.5 \times)$, and were measured using a computer image analysis system. Mean annual densities for the site were calculated.

Long-term biological attributes of lake whitefish were determined from fish that were collected by the Michigan Department of Natural Resources from commercial trap nets in southeastern Lake Michigan. The management zone for lake whitefish in southeastern Lake Michigan extends from the cities of Saugatuck, Michigan, northward to Whitehall, Michigan (Figure 1). Lake whitefish were collected three times each year (spring, summer, autumn) from 1985 to 1999 . Fish were mea-

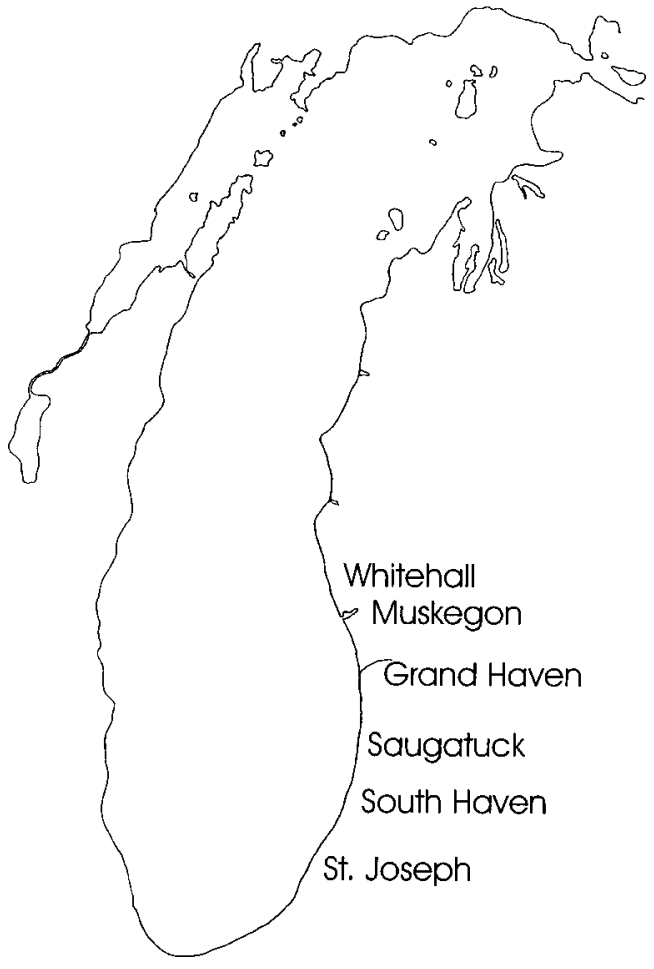

FIGURE 1.-Map of Lake Michigan showing sampling locations for lake whitefish and macroinvertebrates in 1985-2000.

sured (total length), weighed, and scales were removed for estimating age. To evaluate condition for ages 2-16, we used an analysis of covariance (ANCOVA) with fish weight as the response, total length as the covariate, and two periods (19851991 and 1992-1999) as the treatment. Fish length and weight were $\log _{e}$-transformed to meet assumptions of linearity and parallelism. The mean length at age and weight at age of lake whitefish were compared between 1985 and 1991 and 19921998 with separate $t$-tests for ages $2-13$. Older fish were excluded because of small sample size. Length and weight were not transformed because the large sample sizes conformed to the central limit theorem (Zar 1974). The two periods were chosen because zebra mussels were first found in the study area in 1992. We used SYSTAT for all statistical analyses $(\alpha=0.05)$.

Lake whitefish and benthic invertebrates were collected during 1998-2000 off the city of Muskegon, Michigan (Figure 1). Muskegon was chosen for short-term diet analyses because Diporeia had not declined there in early spring 1998 but were expected to do so in the near future (Nalepa 
TABLE 1.-Date, depth, gear type, number of lake whitefish examined, and number of lake whitefish that contained food off five ports in southeastern Lake Michigan in 1998-2000; GN = gill net, BT = bottom trawl.

\begin{tabular}{|c|c|c|c|c|c|}
\hline \multirow[b]{2}{*}{ Port } & \multirow[b]{2}{*}{ Date } & \multirow[b]{2}{*}{ Depth (m) } & \multirow[b]{2}{*}{ Gear } & \multicolumn{2}{|c|}{ Number of fish } \\
\hline & & & & Examined & With food \\
\hline \multirow[t]{12}{*}{ Muskegon } & 18 Jun 1998 & $19-29$ & GN & 59 & 40 \\
\hline & 21 Jun 1998 & 21 & GN & 24 & 21 \\
\hline & 10 Oct 1998 & 20 & GN & 19 & 10 \\
\hline & 19 Oct 1998 & $25-35$ & BT & 12 & 8 \\
\hline & 8 Jun 1999 & 25 & BT & 4 & 4 \\
\hline & 10 Jun 1999 & 25 & GN & 7 & 5 \\
\hline & 24 Jul 1999 & 15 & BT & 41 & 40 \\
\hline & 25 May 2000 & 27 & GN & 25 & 17 \\
\hline & 7 Aug 2000 & 45 & BT & 12 & 12 \\
\hline & 25 Sept 2000 & 45 & BT & 3 & 3 \\
\hline & 11 Oct 2000 & 45 & BT & 3 & 3 \\
\hline & 24 Oct 2000 & 45 & GN & 20 & 19 \\
\hline \multirow{2}{*}{ Grand Haven } & 28 Apr 1999 & 18 & GN & 20 & 15 \\
\hline & 24 Apr 2000 & 18 & GN & 7 & 7 \\
\hline \multirow[t]{4}{*}{ Saugatuck } & 29 Apr 1999 & 18 & GN & 4 & 2 \\
\hline & 4 May 1999 & 18 & GN & 3 & 2 \\
\hline & 27 Apr 2000 & 18 & GN & 25 & 20 \\
\hline & 1 May 2000 & 18 & GN & 9 & 6 \\
\hline South Haven & 6 May 1999 & 18 & GN & 16 & 4 \\
\hline \multirow[t]{4}{*}{ St. Joseph } & 11 May 1999 & 19 & GN & 19 & 12 \\
\hline & 4 Aug 1999 & 34 & GN & 2 & 1 \\
\hline & 31 May 2000 & 18 & GN & 39 & 31 \\
\hline & 5 Jun 2000 & 18 & GN & 1 & 1 \\
\hline
\end{tabular}

et al. 1998). Fish were collected from depths of $15-45 \mathrm{~m}$ using gill nets $(6.4-17.8-\mathrm{cm}$ stretch mesh) and a 7.6-m semiballoon bottom trawl (13mm stretch-mesh cod liner; Table 1). Benthic invertebrates were collected three to eight times each year off Muskegon in conjunction with fish collections using the same sampling protocol described for the long-term study at Grand Haven. Mysis relicta (an opossum shrimp) were collected monthly at night at a 45-m-deep station using a 1$\mathrm{m}$ diameter plankton net $(1,000-\mu \mathrm{m}$ mesh). Lake whitefish were also collected from depths of 18$34 \mathrm{~m}$ using gill nets off Grand Haven, Saugatuck, South Haven, and St. Joseph, Michigan in 19992000. These sites were chosen because Diporeia had declined to negligible levels at each location by 1998 (T. Nalepa, Great Lakes Environmental Research Laboratory, personal communication).

All fish were weighed and measured, and their stomachs were removed and frozen. In the laboratory, stomachs were dissected (esophogus to pyloric caeca), and prey items were identified and counted. Prey lengths of whole organisms were measured using a computer image analysis system (Image-Pro 3.0). Prey length was converted to dry mass using length-weight regressions or species-specific mean weights (Johnson and Brinkhurst 1971; Nalepa and Quigley 1980; Smock 1980; Shea and Makarewicz 1989; Mak- arewicz and Jones 1990; Prejs et al. 1990; T. Nalepa, Great Lakes Environmental Research Laboratory, personal communication). The dry weight of partially digested organisms was assumed to be equal to the mean weight of measured organisms. Micro-zooplankton (e.g., copepods, cladocerans) from stomachs were added to a known volume of water and subsampled with a Hensen-Stemple pipette. Total counts were multiplied by representative mean weights (Hawkins and Evans 1979) and summed to obtain the biomass of microzooplankton in the diet.

Diet was characterized by the percent of the total calculated dry weight for all fish combined and the frequency of occurrence (percent of fish containing a given prey type) as follows: Muskegon 1998; Muskegon 1999-2000; and Grand Haven, Saugatuck, South Haven, and St Joseph 19992000. These three groupings were chosen to represent conditions before, during, and after declines of Diporeia, respectively.

\section{Results}

\section{Macroinvertebrate Community (1980-1999)}

The density of Diporeia at station H31 off Grand Haven exceeded $10,000 / \mathrm{m}^{2}$ during most of the 1980s and early 1990s (Figure 2). After 1992, density declined gradually to $110 / \mathrm{m}$ in 1999 . Zebra 

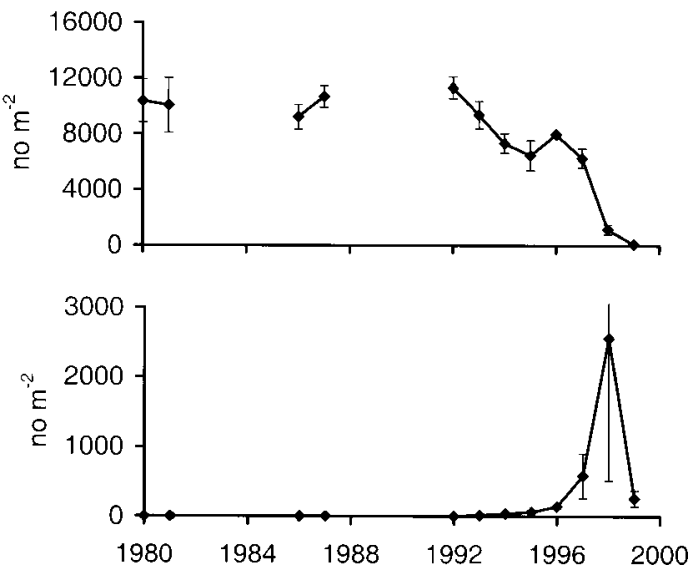

FIgURE 2.-Mean annual density ( $\pm 1 \mathrm{SE}$ ) of Diporeia (upper panel) and zebra mussels (lower panel) at a 45 m-deep station offshore of Grand Haven, Michigan, during 1980-1999. Zebra mussels were first found in 1992 at a density of $2 / \mathrm{m}^{2}$.

mussels were first observed at Grand Haven in 1992 and increased rapidly from densities of 2 $2,561 / \mathrm{m}^{2}$ in 1998 and $258 / \mathrm{m}^{2}$ in 1999 (Figure 2).

\section{Condition and Growth of Lake Whitefish (1985- 1999)}

Compared with the 1985-1991 period, mean weight of lake whitefish adjusted for length declined significantly in $1992-1999(F=1,344$, df $=1,9,555, P<0.01 ;$ Figure 3$)$. The mean adjusted weight of lake whitefish began to decline in 1993 and remained low thereafter. Compared with the 1985-1991 period, mean length at age for ages 210 declined in 1992-1999, but this was not observed for ages 11-13; mean weight at age for ages 2-11 declined in 1992-1999, compared with 1985-1991, but did not change for ages 12-13 (Figure 4; Table 2).

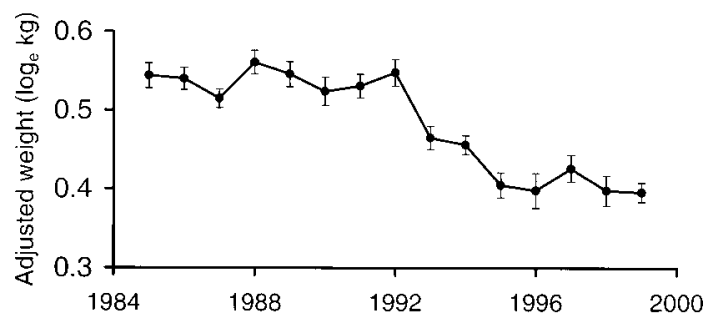

FIGURE 3.- $\log _{e}$-transformed mean weight $(\mathrm{kg}) ; \pm 1$ $\mathrm{SE}$, adjusted for $\log _{e}$-transformed total length ( $\left.\mathrm{mm}\right)$, for lake whitefish (ages 2-16) from commercial trap nets in southeastern Lake Michigan in 1985-1999.
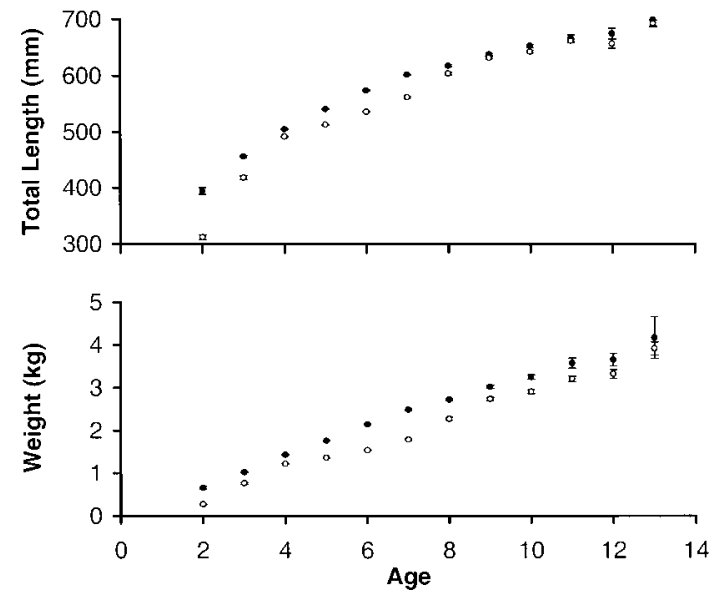

Figure 4.-Mean length at age (top panel) and weight at age (bottom panel) $\pm 1 \mathrm{SE}$ of lake whitefish in southeastern Lake Michigan for 1985-1991 (solid circles) and 1992-1999 (clear circles).

\section{Prey Abundance and Lake Whitefish Diet (1998-} 2000)

The mean density of Diporeia off Muskegon $(15-45 \mathrm{~m})$ declined from $5,569 / \mathrm{m}^{2}$ in 1998 to $1,422 / \mathrm{m}^{2}$ in $1999-2000$. The respective mean densities of other food types-chironomids, zebra mussels, and $M$. relicta-were $123,1,058$, and $121 / \mathrm{m}^{2}$ in 1998 and 129,633 , and $48 / \mathrm{m}^{2}$ in 1999 2000. In 1999-2000, Diporeia was rare or absent off Grand Haven, Saugatuck, South Haven, and St Joseph out to depths of $70 \mathrm{~m}$ (T. Nalepa, Great Lakes Environmental Research Laboratory, personal communication).

A total of 79 (1988) and 103 (1999-2000) lake whitefish off Muskegon contained food (Table 1).

TABLE 2.-Results of $t$-tests (pooled variance) comparing two periods (1985-1991 and 1992-1999) for differences in lake whitefish (Lake Michigan) length at age and weight at age by age-class; $P<0.05$.*

\begin{tabular}{cccr}
\hline & \multicolumn{2}{c}{ Test statistic $(t$-value $)$} & \\
\cline { 2 - 3 } Age & Length & Weight & df \\
\hline 2 & $-11.78^{*}$ & $-12.08^{*}$ & 98 \\
3 & $-11.47^{*}$ & $-11.93^{*}$ & 811 \\
4 & $-6.97^{*}$ & $-13.13^{*}$ & 1,585 \\
5 & $-21.48^{*}$ & $-28.75^{*}$ & 2,416 \\
6 & $-38.74^{*}$ & $-33.59^{*}$ & 1,951 \\
7 & $-20.38^{*}$ & $-27.02^{*}$ & 1,183 \\
8 & $-4.99^{*}$ & $-11.22^{*}$ & 666 \\
9 & $-6.68^{*}$ & $-5.34^{*}$ & 405 \\
10 & $-2.70^{*}$ & $-4.86^{*}$ & 271 \\
11 & -0.73 & $-2.87^{*}$ & 123 \\
12 & -1.17 & -1.65 & 55 \\
13 & -0.58 & -0.65 & 32 \\
\hline
\end{tabular}


TABLE 3.-Percent of total dry weight and frequency of occurrence for diet items of lake whitefish collected from Lake Michigan off Muskegon, Michigan (number of lake whitefish used for analyses, N, = 79 in 1998 and 103 in 1999-2000), and four ports south of Muskegon (Grand Haven, Saugatuck, South Haven, and St. Joseph, Michigan, $N$ $=101$ in 1999-2000).

\begin{tabular}{|c|c|c|c|c|c|c|}
\hline \multirow[b]{2}{*}{ Prey item } & \multicolumn{3}{|c|}{ Percent by weight } & \multicolumn{3}{|c|}{ Frequency of occurrence (\%) } \\
\hline & $\begin{array}{c}\text { Muskegon } \\
1998\end{array}$ & $\begin{array}{l}\text { Muskegon } \\
1999-2000\end{array}$ & $\begin{array}{c}\text { South } \\
1999-2000\end{array}$ & $\begin{array}{c}\text { Muskegon } \\
1998\end{array}$ & $\begin{array}{c}\text { Muskegon } \\
1999-2000\end{array}$ & $\begin{array}{c}\text { South } \\
1999-2000\end{array}$ \\
\hline Diporeia & 70 & 25 & $<1$ & 81 & 45 & 2 \\
\hline Chironomidae & 22 & 27 & 57 & 87 & 68 & 70 \\
\hline D. polymorpha & 8 & 2 & 22 & 67 & 23 & 58 \\
\hline Mysis relicta & 4 & 31 & 6 & 6 & 16 & 12 \\
\hline Sphaeriidae & 5 & 4 & 7 & 95 & 60 & 78 \\
\hline Gastropoda & 5 & $<1$ & 2 & 26 & 13 & 23 \\
\hline Oligochaeta & 0 & $<1$ & $<1$ & 0 & 37 & 24 \\
\hline Ostracoda & 0 & 1 & 1 & 0 & 36 & 19 \\
\hline Isopoda & $<1$ & $<1$ & 0 & 2 & 3 & 0 \\
\hline Gammarus spp. & 2 & $<1$ & 4 & 5 & 1 & 3 \\
\hline Zooplankton & $<1$ & 5 & $<1$ & 6 & 55 & 7 \\
\hline Insecta & $<1$ & $<1$ & $<1$ & 1 & 1 & 2 \\
\hline Fish & 0 & 3 & 0 & 0 & 1 & 0 \\
\hline
\end{tabular}

The length of fish used for diet analyses ranged from 154 to $432 \mathrm{~mm}($ mean $=355 \mathrm{~mm})$ in 1998 and from 165 to $514 \mathrm{~mm}$ (mean $=358 \mathrm{~mm}$ ) in 1999-2000. Diporeia accounted for $70 \%$ of the diet by weight in 1998, but only $25 \%$ in $1998-$ 1999 (Table 3). In contrast, the contribution of $M$. relicta, chironomid larvae and pupae, and zooplankton (mostly Eurycerus lamellatus and B. cederstroemii) increased in the same period. The contribution of zebra mussels (soft tissue only) to the diet by weight was $8 \%$ in 1998 and $2 \%$ in 1999 2000. Lake whitefish ate only relatively small Zebra mussels $(<10 \mathrm{~mm}$ shell length). Other prey items included sphaeriids, gastropods, Gammarus spp. (amphipod), isopods, oligochaetes, ostracods, fish, and insects.

The proportion of lake whitefish from Muskegon that ate Diporeia decreased from $81 \%$ in 1998 to $45 \%$ in 1999-2000 (Table 3). The proportion of lake whitefish that consumed zebra mussels also decreased in the same period from $67 \%$ to $23 \%$. The proportion of lake whitefish that ate chironomids and sphaeriids also decreased between 1998 and 1999-2000, but they were still eaten by a majority $(>60 \%)$ of fish in both periods. In contrast, the proportion of lake whitefish that ate other prey such, as $M$. relicta, ostracods, oligochaetes, and zooplankton, increased between 1998 and 19992000.

A total of 101 lake whitefish off Grand Haven, Saugatuck, South Haven, and St. Joseph contained food in 1999-2000 (Table 1). The length of fish used for diet analyses ranged from 184 to $564 \mathrm{~mm}$ $($ mean $=418 \mathrm{~mm})$. Chironomids and zebra mus- sels accounted for $79 \%$ of the diet by weight at these sites (Table 3). Most lake whitefish (>58\%) ate chironomids, zebra mussels, and sphaeriids at these sites; approximately $20 \%$ consumed ostracods, gastropods, and oligochaetes, although these prey were a small part of the diet by weight. $D i$ poreia accounted for less than $1 \%$ of the diet by weight and were eaten by only $2 \%$ of lake whitefish.

\section{Discussion}

Body condition, length at age (age 2-10), and weight at age (age 2-11) of lake whitefish decreased in southeastern Lake Michigan following the arrival of zebra mussels in 1992. The density of Diporeia also decreased after the proliferation of zebra mussels. The diet of lake whitefish off Muskegon reflected the decline of Diporeia between 1998 and 1999-2000 (i.e., Diporeia was still available but at reduced numbers). A decline in condition after a decline or loss of a high-energy prey item such as Diporeia is consistent with bioenergetic principles (Hanson et al. 1997). Alternative prey such as zebra mussels, chironomids, and M. relicta that are now important in lake whitefish diets, are energetically lower quality food than Diporeia. The caloric content of Diporeia $(4,429$ $\mathrm{J} / \mathrm{g}$ wet mass) is higher than that of chironomids $(2,428 \mathrm{~J} / \mathrm{g})$, zebra mussels (soft tissue) $(1,047-$ $2,478 \mathrm{~J} / \mathrm{g})$, and $M$. relicta $(2,972-4,312 \mathrm{~J} / \mathrm{g}$; Schneider 1992; Hanson et al. 1997). Reduced densities of Diporeia could increase the foraging time needed to maintain the same ration that a lake whitefish obtains at higher Diporeia densities. Im- 
portant alternative prey such as chironomids appear to be relatively uncommon in southeastern Lake Michigan, and use of this prey could result in increased search times.

The changes in diet composition of lake whitefish in southeast Lake Michigan are generally consistent with observations from Lakes Ontario and Erie, where diet consisted mainly of Dreissena spp. and other peleycypods after Diporeia disappeared (Hoyle et al. 1999; Cornelius 2000). Lake whitefish off Muskegon consumed zebra mussels before the significant Diporeia declines. Zebra mussels could reduce lake whitefish growth if indigestible shell material reduces the overall ration of a fish. Shell material accounts for $67-94 \%$ of the total dry weight of zebra mussels (French and Bur 1993). Shell material does not contribute to a fish's diet energetically but takes space in the digestive tract. Condition of lake whitefish in Lake Ontario decreased with the consumption of Dreissena spp. (Hoyle et al. 1999). In Lake Erie, freshwater drum Aplodinotus grunniens that supplemented their diet with zebra mussels grew slower than they did before the arrival of zebra mussels (French and Bur 1996). Other prey types, such as gastropods and sphaeriids, also contain a high percentage of indigestible shell material and may further contribute to decreases in energy intake in the absence of the high-energy prey Diporeia.

A high percentage of lake whitefish ate smallbodied prey such as zooplankton, ostracods, and oligochaetes after Diporeia declined off both Muskegon and ports further south. Consumption of small-bodied prey could reduce energy intake for lake whitefish. Populations of lake whitefish in Lake Huron, Lake Ontario, and inland Canadian lakes that ate large macroinvertebrates such as $\mathrm{Di}$ poreia grew faster than those that ate smaller prey such as zooplankton and small mollusks (Ihssen et al. 1981). This difference may be due to the increased energy expenditure required to locate, capture, handle, and process smaller prey (Ihssen et al. 1981).

Body condition and growth of lake whitefish could also decrease because of density-dependence. In southeastern Lake Michigan, mean catch per effort of lake whitefish in commercial trap nets increased from $118 \mathrm{~kg} / \mathrm{lift}$ in $1985-1991$ to 192 kg/lift in 1992-1998 (P. Schneeberger, Michigan Department of Natural Resources,unpublished data). Length at age of lake whitefish decreased with increased abundance in inland Canadian lakes and in Lake Huron (Healey 1980; Spangler and Collins 1980; Henderson et al. 1983). Weight at age of lake whitefish also decreased with abundance, but the trend was more variable (Healey 1980); however, Henderson et al. (1983) reported reduced growth mainly affected ages $2-3$. In contrast, we found decreases in length at age for ages $2-10$ and weight at age for ages $2-11$. Densitydependent growth reductions are attributed to competition for food (Henderson et al. 1983), so the changes we found in food quality and quantity will exacerbate any effects of higher densities of lake whitefish.

In the future, zebra mussel-related effects are expected to worsen and spread throughout Lake Michigan. Quagga mussels were recently found in Lake Michigan and could cause a rapid acceleration of Dreissena-related impacts in the lake (Nalepa et al. 2001). Body condition and growth of lake whitefish are already decreasing in northern areas of Lake Michigan (P. Peeters, Wisconsin Department of Natural Resources, personal communication), and Diporeia began to decrease in northern Lake Michigan in 1999-2000 (T. Nalepa, Great Lakes Environmental Research Laboratory, personal communication). Commercial harvest of lake whitefish will probably decrease because of poor growth and body condition, so fishery managers may need to adjust minimum length limits if the age at which fish are recruited to the fishery increases. Fishery managers could also increase harvest quotas to reduce density-dependant competition. If recruitment declines with lower condition, abundance of lake whitefish may also decrease, unless management successfully intervenes. Recruitment of lake whitefish decreased in Lake Ontario in association with Dreissena invasion and Diporeia declines (Hoyle et al. 1999).

Lake whitefish might move to deeper waters where Diporeia (Nalepa et al. 2000) and other large prey such as Mysis relicta are more abundant (Reynolds and DeGraeve 1972). Alewives Alosa pseudoharengus, rainbow smelt Osmerus mordax, and juvenile lake trout Salvelinus namaycush moved to deeper water in Lake Ontario following Dreissena invasion (O'Gorman et al. 2000). Although food is more abundant in deeper water, there are energetic costs associated with feeding in colder water (O'Gorman et al. 2000). If lake whitefish move further offshore, they may become unavailable to trap nets, which are legislatively restricted to depths less than $27 \mathrm{~m}$ in Michigan.

Our results generate further questions about the ecology of lake whitefish for future studies. First, laboratory studies need to address how the feeding efficiency of lake whitefish depends on prey type, 
size, and density. Second, the energy density of native and introduced macroinvertebrates in the Great Lakes needs to be evaluated. Most energy density data on invertebrates was determined in studies that occurred outside the Great Lakes region (Schneider 1992; Hanson et al. 1997), and the energy content of native macroinvertebrates may be changing in response to Dreissena invasion (Nalepa et al. 2000). Finally, an index of the recruitment and abundance of lake whitefish, independent of the commercial fishery, is needed.

\section{Acknowledgments}

Assistance in the laboratory and field was provided by the crews of the $R / V$ Shenehon, $R / V$ Laurentian, S/V Steelhead, F/V Bob Richard, and $F / V$ Mabel, including E. Gaereminck, S. Rypma, N. Lieberman, D. Hartson, D. Fanslow, D. Hondorp, J. Jonas, D. Clapp, J. Meggison, J. Harris, J. Ranville, B. Flood, B. Tolles, M. Tonello, D. Dupras, K. Koval, G. Kleaver, J. Knape, R. Rybicki, R. O'Neal, A. Hilt, and J. Trimberger. Funding was provided by National Oceanic and Atmospheric Administration, Michigan Department of Natural Resources, and the Great Lakes Fishery Trust. This is Great Lakes Environmental Research Laboratory contribution 1214 .

\section{References}

Baldwin, N. A., R. W. Saalfeld, M. R. Dochoda, H. J. Buettner, and R. L. Eshenroder. 2000. Commercial fish production in the Great Lakes. Great Lakes Fishery Commission, Ann Arbor, Michigan. (Available at http://www.glfc.org/databases/commerc.asp)

Cornelius, F. C. 2000. New York's Lake Erie fisheries: response to change. Great Lakes Research Review $5: 1-12$.

Dermott, R., and D. Kerec. 1997. Changes in the deepwater benthos of eastern Lake Erie since the invasion of Dreissena, 1979-1993. Canadian Journal of Fisheries and Aquatic Sciences 54:922-930.

Fleischer, G. W. 1992. Status of coregonine fishes in the Laurentian Great Lakes. Polskie Archiwum Hydrobiologii 39:247-259.

French, J. R. P., and M. T. Bur. 1993. Predation of the zebra mussel (Dreissena polymorpha) by freshwater drum in western Lake Erie. Pages 453-464 in T. F. Nalepa and D. W. Schloesser, editors. Zebra mussels: biology, impacts, and control. Lewis Publishers, Boca Raton, Florida.

French, J. R. P., and M. T. Bur. 1996. The effect of zebra mussel consumption on growth of freshwater drum in Lake Erie. Journal of Freshwater Ecology 11: 283-289.

Gardner, W. S., T. F. Nalepa, W. A. Frez, E. A. Cichocki, and P. F. Landrum. 1985. Seasonal patterns in lipid content of Lake Michigan macroinvertebrates. Ca- nadian Journal of Fisheries and Aquatic Sciences 42:1827-1832.

Hanson, P. C., T. B. Johnson, E. E. Schindler, and J. F. Kitchell. 1997. Fish bionergetics 3.0. University of Wisconsin System, Sea Grant Institute, Madison.

Hawkins, B. E., and M. E. Evans. 1979. Seasonal cycles of zooplankton biomass in southeastern Lake Michigan. Journal of Great Lakes Research 5:256-263.

Healey, M. C. 1980. Growth and recruitment in experimentally exploited lake whitefish (Coregonus clupeaformis) populations. Canadian Journal of Fisheries and Aquatic Sciences 37:255-267.

Henderson, B. A., J. J. Collins, and J. A. Reckahn. 1983. Dynamics of an exploited population of lake whitefish (Coregonus clupeaformis) in Lake Huron. Canadian Journal of Fisheries and Aquatic Sciences 40:1556-1567.

Hoyle, J. A., T. Schaner, J. M. Casselman, and R. Dermott. 1999. Changes in lake whitefish (Coregonus clupeaformis) stocks in eastern Lake Ontario following Dreissena mussel invasion. Great Lakes Research Review 4:5-10.

Ihssen, P. E., D. O. Evans, W. J. Christie, J. A. Reckahn, and R. L. DesJardine. 1981. Life history, morphology, and electrophoretic characteristics of five allopatric stocks of lake whitefish (Coregonus clupeaformis) in the Great Lakes region. Canadian Journal of Fisheries and Aquatic Sciences 38:17901807.

Johnson, M. G., and R. O. Brinkhurst. 1971. Production of benthic macroinvertebrates of Bay of Quinte and Lake Ontario. Journal of Fisheries Research Board of Canada 28:1699-1714.

Jude, D. J., H. T. Tin, G. R. Heufelder, P. J. Schneeberger, C. P. Madenjian, T. L. Rutecki, P. M. Mansfield, N. A. Auer, and G. E. Noguchi. 1981. Adult, juvenile and larval fish populations in the vicinity of the $\mathrm{J}$. H. Cambell power plant, eastern Lake Michigan, 1977-1980. University of Michigan, Great Lakes Research Division, Special Report 86, Ann Arbor, Michigan.

Makarewicz, J. C., and H. D. Jones. 1990. Occurrence of Bythotrephes cederstroemi in Lake Ontario offshore waters. Journal of Great Lakes Research 16: 143-147.

Marsden, J. E., N. Trudeau, and T. Keniry. 1993. Zebra mussel study of Lake Michigan. Illinois Natural History Survey, Aquatic Ecology Technical Report 93/14.

Nalepa, T. F., D. J. Hartson, J. Buchanan, J. F. Cavaletto, G. A. Lang, and S. J. Lozano. 2000. Spatial variation in density, mean size, and physiological condition of the holarctic amphipod Diporeia spp. in Lake Michigan. Journal of Freshwater Biology 43: $107-119$.

Nalepa, T. F., D. J. Hartson, D. L. Fanslow, G. A. Lang, and S. J. Lozano. 1998. Declines in benthic macroinvertebrate populations in southern Lake Michigan, 1980-1993. Canadian Journal of Fisheries and Aquatic Sciences 55:2402-2413.

Nalepa, T. F., and M. A. Quigley. 1980. The macro- and meiobenthos of southeastern Lake Michigan near 
the mouth of the Grand River, 1976-77. Great Lakes Environmental Research Laboratory, National Oceanic and Atmospheric Administration data report ERL GLERL-17, Ann Arbor, Michigan.

Nalepa, T. F., D. W. Schloesser, S. A. Pothoven, D. W. Hondorp, D. L. Fanslow, M. L. Tuchman, and G. W. Fleischer. 2001. First finding of the amphipod Echinogammarus ischnus and the mussel Dreissena bugensis in Lake Michigan. Journal of Great Lakes Research 27:384-391.

O'Gorman, R., J. H. Elrod, R. W. Owens, C. P. Schneider, T. H. Eckert, and B. F. Lantry. 2000. Shifts in distribution of alewives, rainbow smelt, and age-2 lake trout in southern Lake Ontario following establishment of dreissenids. Transactions of the American Fisheries Society 129:1096-1106.

Prejs, A., K. Lewandowskim, and A. StanczykowskaPiotrowska. 1990. Size-selective predation by roach (Rutilus rutilus) on zebra mussels (Dreissena polymorpha): field studies. Oecologia 83:378-384.

Reynolds, J. B., and G. M. DeGraeve. 1972. Seasonal population characteristics of the opposum shrimp, Mysis relicta, in southeastern Lake Michigan, 197071. Pages 117-131 in Proceedings of the 15th Con- ference of Great Lakes Research. International Association of Great Lakes Research, Ann Arbor, Michigan.

Schneider, D. W. 1992. A bioenergetics model of zebra mussel, Dreissena polymorpha, growth in the Great Lakes. Canadian Journal of Fisheries and Aquatic Sciences 49:1406-1416.

Shea, M. A., and J. C. Makarewicz. 1989. Production, biomass, and trophic interaction of Mysis relicta in Lake Ontario. Journal of Great Lakes Research 15: 223-232.

Smock, L. A. 1980. Relationship between body size and biomass of aquatic insects. Freshwater Biology 10: 375-383.

Spangler, G. R., and J. J. Collins. 1980. Response of lake whitefish (Coregonus clupeaformis) to the control of sea lamprey (Petromyzon marinus) in Lake Huron. Canadian Journal of Fisheries and Aquatic Sciences 37:2039-2046.

Wells, L., and A. L. McLain. 1973. Lake Michigan: man's effects on native fish stocks and other biota. Great Lakes Fishery Commission Technical Report Number 20.

Zar, J. H. 1974. Biostatistical Analysis. Prentice-Hall, Englewood Cliffs, New Jersey. 